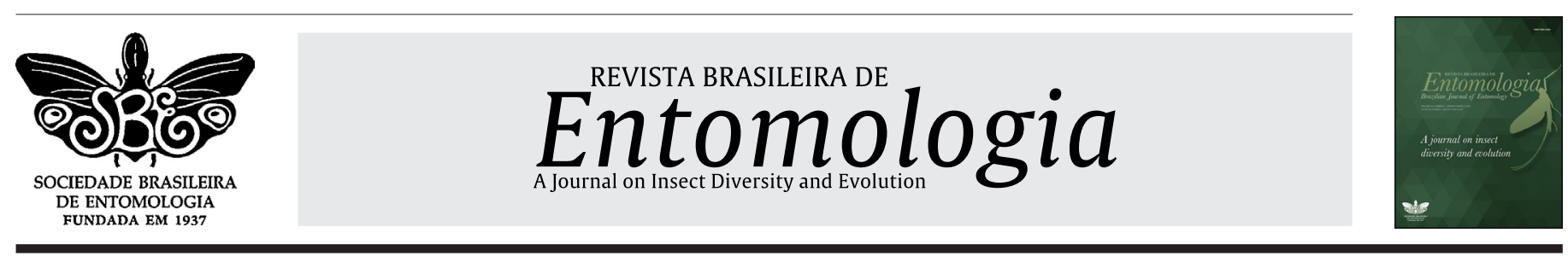

\title{
New, additional and historical records of Leptophlebiidae (Insecta, Ephemeroptera) from Colombia
}

\author{
Jhon Faber Marulanda Lopez $z^{1,2}$,* $@$, Isabel Cristina Hernández², \\ Lucimar Gomes Dias², Frederico Falcão Salles ${ }^{1}$
}

${ }^{1}$ Universidade Federal de Viçosa, Departamento de Entomologia, Museu de Entomologia, Viçosa, MG, Brasil.

${ }^{2}$ Universidad de Caldas, Facultad de Ciencias Exactas y Naturales, Grupo de Investigación Bionat, Manizales, Caldas, Colombia.

\section{A R T I C L E I N F O}

Article history:

Received 28 June 2020

Accepted 10 August 2020

Available online 7 September 2020

Associate Editor: Douglas Zeppelini

\section{Keywords:}

Amazon

Andes

Diversity

Mayflies

Neotropical Region

\begin{abstract}
A B S T R A C T
In the Neotropical region, especially South America, Leptophlebiidae achieves its higher diversity, with 45 genera and almost 250 species. In Colombia, the diversity about this family is underestimated, with only 22 species reported so far. In order to contribute to the current knowledge of the Leptophlebiidae in Colombia we examined the adults of this family deposited at the Colección Entomológica del Programa de Biología, Universidad de Caldas. In addition to the historical records herein presented, nine species are registered for the first time from the country (Farrodes savagei, F. tepui, F. xingu, Hagenulopsis minuta, Terpides contamanensis, T. echinovaris, T. ornatodermis, Tikuna atramentum, and Ulmeritoides flavopedes). Besides that, additional records are presented for 12 species of the following genera: Askola, Farrodes, Simothraulopsis, Tikuna, Ulmeritoides, Hydrosmilodon, Terpides, Choroterpes, Paramaka, and Hagenulopsis. With these additional and new records, we update the list of Leptophlebiidae from Colombia to 33 species and 14 genera.
\end{abstract}

\section{Introduction}

Leptophlebiidae is one of the most diversified groups of mayflies (Ephemeroptera), both taxonomically and ecologically, with more than 640 species and 140 genera distributed worldwide (Sartori and Brittain, 2015). The family represents an important component of freshwater ecosystems, especially in the Southern Hemisphere (Savage, 1987b).

Historically, the family was divided in two subfamilies, Leptophlebiinae Banks and Atalophlebiinae Peters (Peters, 1980). While Leptophlebiinae was represented by few genera and species mostly restricted to the Northern Hemisphere, Atalophlebiinae included more than 100 described genera and more than 500 species and presents a gondwanan distribution with some taxa spreading to the north (O'Donnell and Jockusch, 2008). Nowadays, however, the family is divided into eight subfamilies, due to the split of both Leptophlebiinae (in Leptophlebiinae s.s., Habrophlebiinae, and Calliarcyinae) and Atalophlebiinae (in Atalophlebiinae s.s., Terpidinae, Castanophlebiinae, Choroterpinae, and Hagenulinae) (Kluge, 2009; Godunko et al., 2015; Monjardim et al., 2020).

The Neotropics, especially South America, is where Leptophlebiidae achieves its higher diversity. In this region, more than 45 genera and

\footnotetext{
* Corresponding author:

E-mail: jhon.lopez@ufv.br (J.F. M. Lopez)
}

240 species are reported, belonging to Atalophlebiinae, Choroterpinae, Hagenulinae, and to the endemic Terpidinae (Domínguez et al., 2006; Kluge, 2015; Zúñiga et al., 2015; Salles and Boldrini, 2019; Monjardim et al., 2020; Salles et al., 2020a). Nevertheless, the average of new species published every year is still high and many taxa remain to be described from the region.

Colombia is recognized as one of the most biodiversity rich countries in the Neotropic (Andrade, 2011). A huge variety of ecosystems, such as "tropical forests in the Amazon and Choco, mountain habitats like the Sierra Nevada and Andes, the grasslands of the plains and badlands, and islands like Gorgona in the Pacific and San Martin in the Caribbean", is the main reason for such biodiversity. Unfortunately, given the high rates of biodiversity loss, some areas in the country are among the most hotspots for biodiversity in the World (Myers et al., 2000; Poveda et al., 2010).

Concerning mayflies it is clear that the diversity in Colombia is underestimated. Currently, only 120 species are known: 32 species for Baetidae, eight for Caenidae, one for Coryphoridae, three for Ephemeridae, two for Euthyplociidae, 28 for Leptohyphidae, 22 for Leptophlebiidae, three for Oligoneuriidae, and 21 for Polymitarcyidae (Dias and Marulanda, 2019; Domínguez et al., 2019; Molineri et al., 2019; 
Salles et al., 2020b). These numbers, especially for Leptophlebiidae and Baetidae, are far from the actual number. In South American countries where the mayfly components have been studied more often, such as Brazil and Argentina, the number of species of this families surpasses one hundred and many species remain to be described.

Based on material collected by L.G. Dias team in the last years and deposited at the Entomological Collection of the Biology program of the Caldas University - CEBUC, our aim is to increase the knowledge of Leptophlebiidae from Colombia by presenting new and additional records of the family from the country.

\section{Material \& Methods}

Identification

We examined and mounted the male genitalia and wings of imagos in permanent slides using Euparal ${ }^{\circledR}$. For the identification of the collected insects taxonomic keys and original descriptions were used (Walker, 1853; Eaton, 1883, 1892; Needham and Murphy, 1924; Spieth, 1943; Traver, 1943, 1947; Traver and Edmunds, 1967; Savage and Peters, 1983; Flowers, 1987; Savage, 1987a; Domínguez et al., 1996; Domínguez, 1999; Domínguez and Zúñiga, 2003; Peters et al., 2008; Kluge, 2009, 2015; Zúñiga et al., 2015; Salles et al., 2018).

\section{Occurrence maps}

We made the maps of occurrence in South America with the software ESRI ${ }^{\circledR}$ ArcMap 10.0, using a digital model of the elevation with countries delimitation in the Neotropic. Records from the literature were obtained from the following publications: Needham and Murphy (1924); Traver and Edmunds (1967); Savage and Peters (1983); Zúñiga et al. (1997); Mosquera et al. (2001); Domínguez and Zúñiga (2003); Zúñiga et al. (2004); Peters et al. (2008); Domínguez and Zúñiga (2009); Domínguez et al. (2009); Salinas-Jiménez et al. (2013); Zúñiga et al. (2014, 2015); Rozo and Salinas-Jiménez (2016); Salinas-Jiménez et al. (2017, 2018); Salles et al. (2018).

Images

We took pictures of specimens deposited in alcohol using LEICA M205 A and LEICA M205 C stereo microscopes with LEICA MC170 HD digital cameras. Pictures of living specimens in the field were taken with a Nikon d800 camera, $105 \mathrm{~mm}$ macro lens, a SB-5000 Nikon flash, and a small acrylic aquarium. Post-processing of pictures were made in Adobe Lightroom ${ }^{\circledR}$ and the final plates were prepared in Adobe Illustrator ${ }^{\circledR}$ and Adobe Photoshop ${ }^{\circledR}$.

Deposition

We deposited the material in the Colección Entomológica del Programa de Biología, Universidad de Caldas (CEBUC), Manizales, Colombia, and at the Museu de Entomologia, Universidade Federal de Viçosa (UFVB), Viçosa, Brazil. In the case of Terpidinae, all specimens are temporarily deposited at the UFVB.

\section{Results}

Based on the specimens available at the CEBUC, we identified 21 species of Leptophlebiidae. Eleven of them (belonging to the genera Askola Peters, 1969; Farrodes Peters, 1971; Simothraulopsis Demoulin, 1966; Tikuna Savage, Flowers \& Porras, 2005; Ulmeritoides Traver, 1959;
Hydrosmilodon Flowers \& Domínguez, 1992; Terpides Demoulin, 1966; and Hagenulopsis Ulmer, 1920), were already reported from Colombia and, thus, represent additional records for the country. Farrodes savagei Domínguez, 1999; F. tepui Domínguez, Molineri \& Peters, 1996; F. xingu Domínguez, Molineri \& Peters, 1996; Terpides contamanensis Kluge, 2015; T. echinovaris Kluge, 2015; T. ornatodermis Kluge, 2015; Tikuna atramentum (Traver, 1947); Hagenulopsis minuta Spieth, 1943; and Ulmeritoides flavopedes (Spieth, 1943) represent new records for the country. We also present records for a new species of Choroterpes Eaton, 1881 and a new species of Paramaka Savage \& Domínguez, 1992. With these new and additional records, we update the total number of Leptophlebiidae known from Colombia to 33 species and 14 genera. Importantly, given the diversity of Thraulodes in Colombia, the new species of this genus that were found in CEBUC will be treated elsewhere (Hernández in prep.).

A complete list of the species of Leptophlebiidae reported from Colombia is presented below. For species reported for the first time from the country, the specific name is succeeded by an asterisk $\left({ }^{*}\right)$.

\section{Hagenulinae}

Askola emmerichi Domínguez et al., 2009 (Figs. 1A and 2B)

Previous distribution: COLOMBIA: Amazonas department (Domínguez et al., 2009: 31); Venezuela: Bolivar state (Domínguez et al., 2014: 302); BRAZIL: Amazonas state (Nascimento et al., 2011: 200), Roraima state (Santos and Boldrini, 2016: 2), Bahia state (Lima et al., 2016: 216; Costa et al., 2018: 4), Pernambuco state (Campos et al., 2019: 36), Maranhão state (Nascimento et al., 2020: 581).

Additional records from Colombia: 2 male imagos, Putumayo department, Puerto Asís, Quebrada La Ventura (0³7'15.8”N 76³4'33.6”W), 19/xii/2015, light trap night, deposited at CEBUC; 88 male and 5 female imagos, Putumayo department, Puerto Asís, Quebrada Agua Negra (0³1'36.3” $\mathrm{N} \mathrm{76}{ }^{\circ} 31^{\prime} 38.3$ ”W), 17, 19 and 20/xii/2015, light trap night, deposited at CEBUC; 3 male imagos, Amazonas department, Leticia, 2017, light trap, deposited at CEBUC.

Atopophlebia caldasi Salles, Marulanda \& Dias, 2018

(Figs. 1B, 2B and 3D)

Previous distribution: COLOMBIA, Caldas department, Norcasia and Samaná (Salles et al., 2018: 140).

Additional records from Colombia: 1 nymph, Tolima department, San Sebastián de Mariquita, Cataratas de Medina stream ( $5^{\circ} 14^{\prime} 41.09^{\prime \prime} \mathrm{N}$ 7453’06.97”W), 14/ii/2020, deposited at UFVB.

Atopophlebia fortunensis Flowers, 1987 (Fig. 2B)

Previous distribution: COLOMBIA, Valle del Cauca department, Pavas (Zúñiga et al., 1997; Mosquera et al., 2001); COSTA RICA: Cartago Province; (Flowers, 1987: 205); PANAMA: Chiriquí and Bocas del Toro Provinces (Flowers, 1980: 164, 1987:205).

Additional records from Colombia: none.

Atopophlebia pacis Salles, Marulanda \& Dias, 2018 (Fig. 2B)

Previous distribution: COLOMBIA, Putumayo department, Mocoa and Puerto Asís (Salles et al., 2018: 139). 


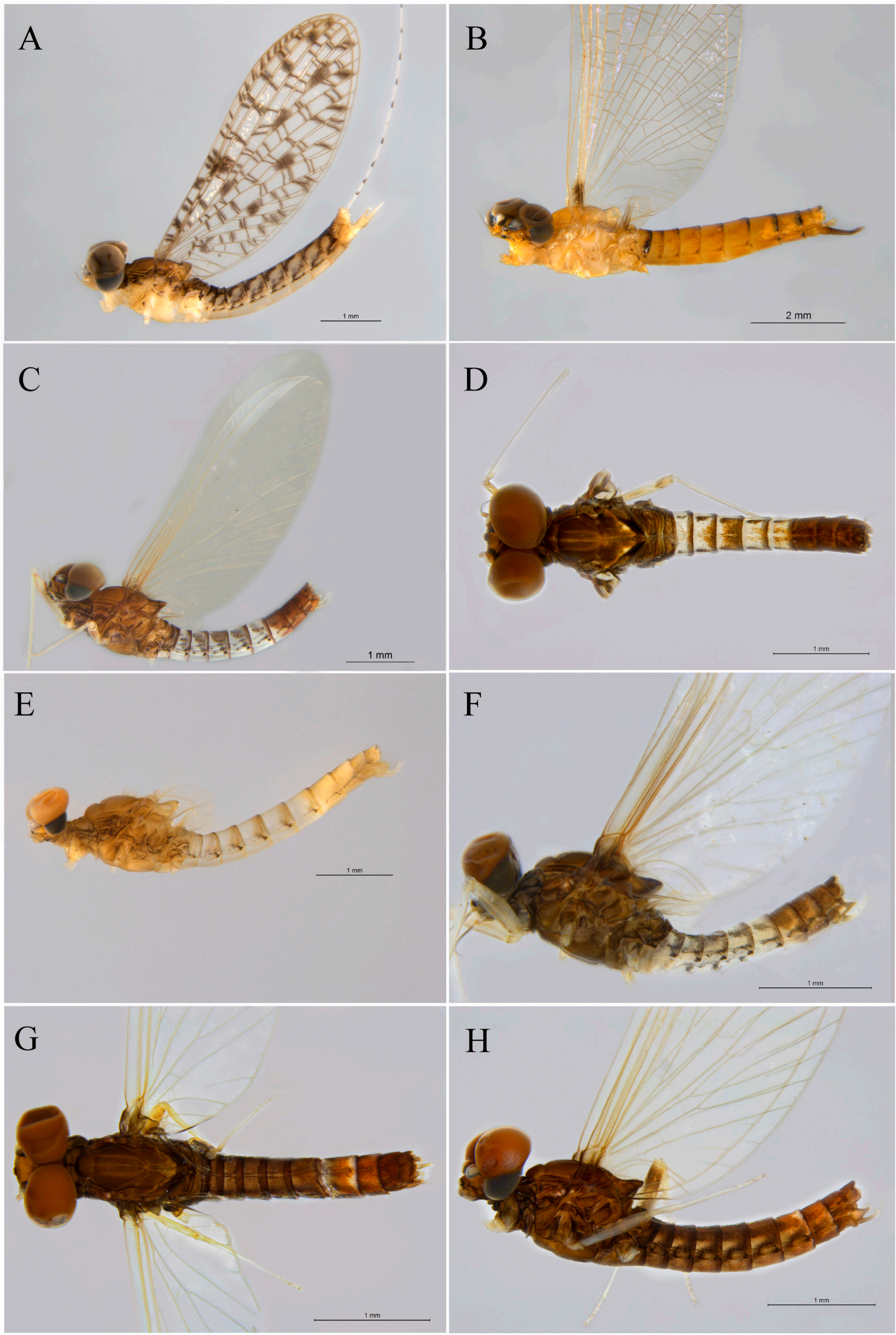

Figure 1. Habits of male imagos of Leptophlebiidae species: A) lateral view of Askola emmerichi; B) lateral view of Atopophlebia caldasi; C) lateral view of Farrodes caribbianus; and D) dorsal view of Farrodes caribbianus; E) lateral view of F. roundsi; F) lateral view of $F$. savagei; G) dorsal view of $F$. tepui; and H) lateral view of $F$. tepui. 


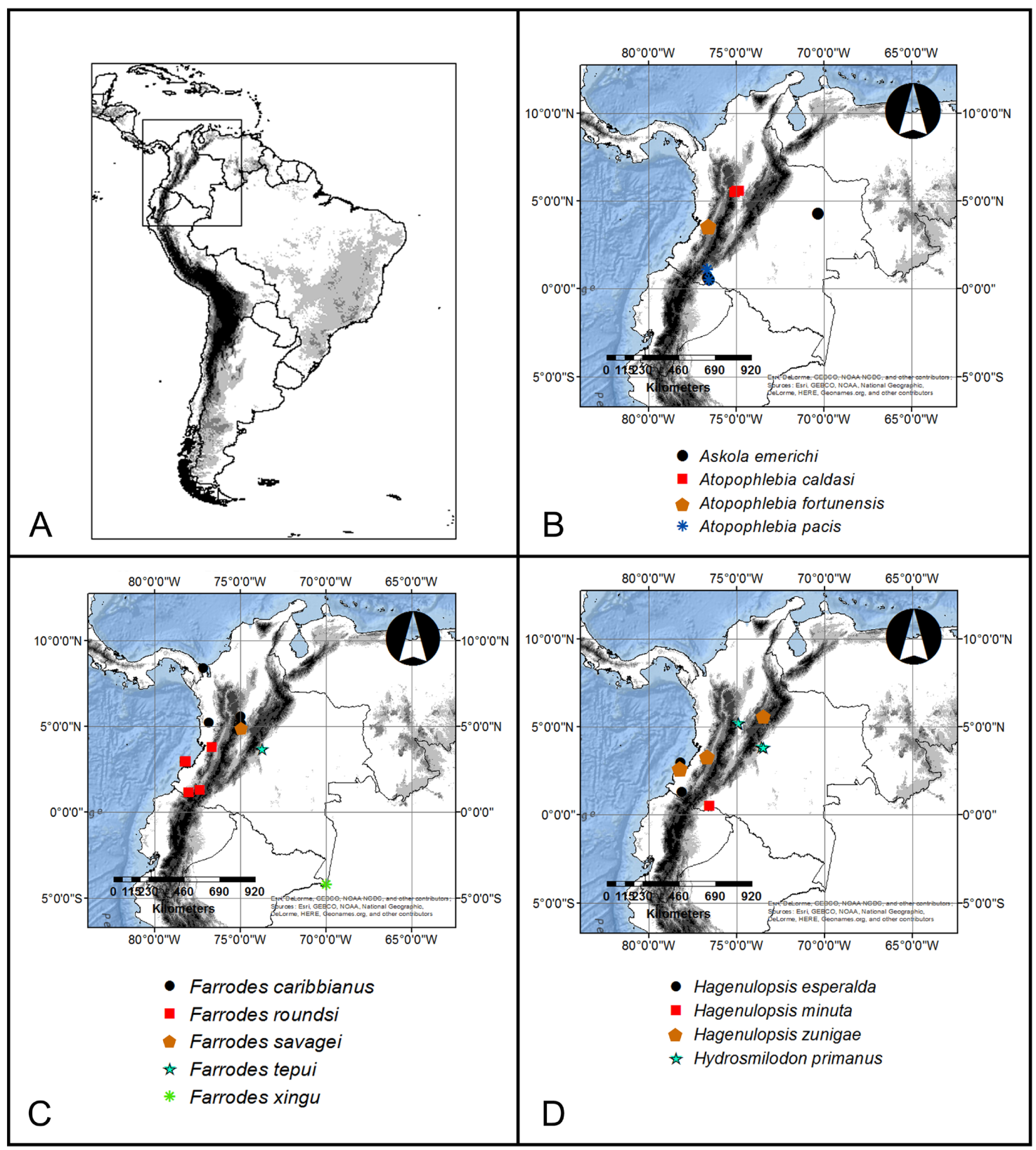

Figure 2. Maps of South America with detail of Colombia showing the distribution of the species of Leptophlebiidae: A) map of South America with detail of Colombia; B) Askola emerichi and Atopophlebia spp.; C) Farrodes spp.; D) Hagenulopsis spp. and Hydrosmilodon primanus.

Additional records from Colombia: none.

Farrodes caribbianus (Traver, 1943) (Figs. 1C-D and 2C)

Previous distribution: COLOMBIA, Choco department, Acandí (Zúñiga et al., 2004: 36; Rozo and Salinas-Jiménez, 2016: 8), Cauca department, Parque Nacional Natural Gorgona (Zúñiga et al., 2014: 234); COSTA RICA: Guanacaste Province (Domínguez, 1999: 159; Chacón et al., 2009: 726); VENEZUELA: Bolivar state (Domínguez, 1999: 159; Chacón et al., 2009: 726; Domínguez et al., 2014: 304); PANAMA: Canal de Panama (Domínguez, 1999: 159); NICARAGUA: Río San Juan department (Meyer et al., 2008: 140).

Additional records from Colombia: 3 male imagos, Tolima department, Armero Guayabal, Quebrada Santo Domingo - Granja Universidad del
Tolima (500'06.0"N 7454'08.0”W), 19/v/2017, light trap, deposited at CEBUC; 2 male imagos, Tolima department, Mariquita, Villa de los Caballeros (509'21.42”N 7453'58.32”W), 21/v/2017, light trap, deposited at CEBUC; 2 male imagos, Tolima department, Mariquita, Villa de los Caballeros (509'21.42"N 7453'58.32”W), 21/v/2017, light trap, deposited at UFVB.

Farrodes roundsi (Traver, 1947) (Figs. 1E and 2C)

Previous distribution: COLOMBIA: Nariño and Valle del Cauca departments (Zúñiga et al., 2004: 36), Pasto department, Reserva Natural La Planada (Domínguez and Zúñiga, 2009: 74), Cauca department, Parque Nacional Natural Gorgona (Zúñiga et al., 2014: 227; Zúñiga et al., 2015: 294); COSTA RICA: Guanacaste Province 
(Domínguez, 1999: 161); PANAMA: Chiriquí Province (Domínguez, 1999: 161).

Additional records from Colombia: 1 male imago, Nariño, Reserva Natural Río Ñambi ( $1^{\circ} 18^{\prime} 00$ ”N 7404'58.79”W), 01/iii/2013, light trap, deposited at CEBUC.

Farrodes savagei * Domínguez, 1999 (Figs. 1F and 2C)

Previous distribution: VENEZUELA: Zulia state (Domínguez, 1999: 164; Chacón et al., 2009: 726); NICARAGUA: Reserva de la Biosfera Bosawas (Meyer et al., 2008: 140).

New record from Colombia: 2 male imagos, Tolima department, Armero Guayabal, Quebrada Santo Domingo - Granja Universidad del Tolima (500'18.15"N 7454'24.78”W), 19/xi/2017, light trap, deposited at UFVB; 1 male and 1 female imagos, same data, deposited at CEBUC.

Farrodes tepui * Domínguez, Molineri \& Peters, 1996

(Figs. $1 \mathrm{G}-\mathrm{H}$ and $2 \mathrm{C}$ )

Previous distribution: BRAZIL: Pernambuco (Lima et al., 2012: 309) and Bahia states (Lima et al., 2016: 217); VENEZUELA: Amazonas state (Domínguez et al., 1996: 98); FRENCH GUIANA: Amazonas state (Chacón et al., 2009: 726).
New record from Colombia: 3 male and 4 female imagos, Meta department, San Martín, Caño Camoa ( $3^{\circ} 41^{\prime} 24.72$ ”N 7341'59.41”W), 04/i/2015, light trap, deposited at UFVB; 4 male and 4 female imagos, same data, deposited at CEBUC.

Farrodes xingu * Domínguez, Molineri \& Peters, 1996 (Figs. 2C and 4A-B)

Previous distribution: BRAZIL: Pará state (Domínguez et al., 1996: 97), Mato Grosso state (Santos et al., 2019: 203); and Maranhão state (Nascimento et al., 2020: 581).

New record from Colombia: 10 male and 4 female imagos, Amazonas department, Leticia, Quebrada La Arenosa (4¹2'11.39”S 6956’09.26”W), 28/ix/2014, light trap, deposited at UFVB; 11 male and 5 female imagos, same data, deposited at CEBUC.

Hagenulopsis esmeralda Domínguez et al., 2009 (Figs. 2D and 3A-B)

Previous distribution: COLOMBIA: Cauca department, Parque Nacional Natural Gorgona (Zúñiga et al., 2014: 226; 2015: 294); ECUADOR: Esmeralda Province (Domínguez et al., 2009: 40).

Additional record from Colombia: 2 male imagos, Nariño department, Reserva Natural Río Ñambi ( $\left.1^{\circ} 18^{\prime} 00^{\prime \prime N} 74^{\circ} 04^{\prime} 58.79 ” W\right), 01 /$ iii/2013, light trap, deposited at CEBUC.
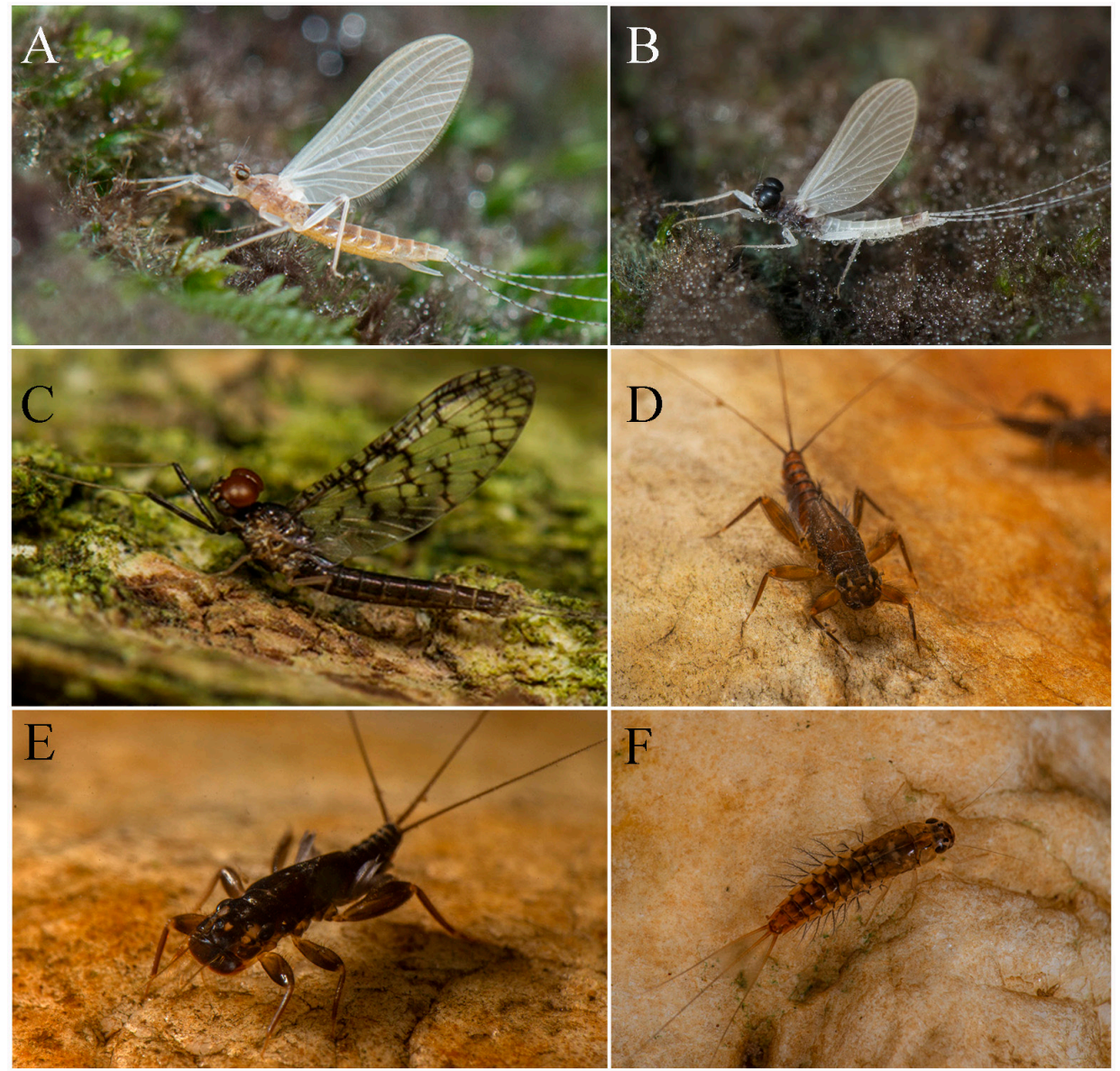

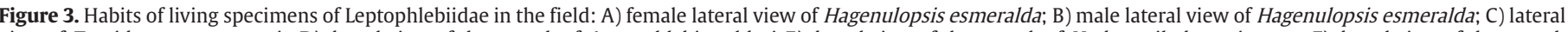

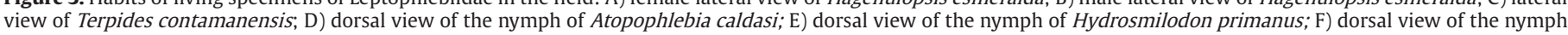
of Terpides echinovaris. 
Hagenulopsis minuta* (Spieth, 1943) (Figs. 2D and 4C-D)

Previous distribution: BRAZIL: Roraima (Gama Neto and Hamada, 2014: 279), and Bahia states (Lima et al., 2016: 217); SURINAME: Rio Marowijne (Peters and Domínguez, 2001: 354); VENEZUELA: Amazonas state (Peters and Domínguez, 2001: 354; Chacón et al., 2009: 726).

New record from Colombia: 6 male imagos, Putumayo department, Puerto Asís, Quebrada Agua Negra (0³1’36.3”N 76³1’38.3”W), 20/xii/2015, light trap, deposited at UFVB; 15 male imagos, same data: deposited at CEBUC; 60 male and 4 female imagos, same data, deposited at CEBUC.

Hagenulopsis zunigae Domínguez et al., 2009 (Fig. 2D)

Previous distribution: COLOMBIA: Valle del Cauca department, Parque Nacional Natural Farallones de Cali, Boyaca department, Arcabuco (Domínguez et al., 2009: 41), Cauca department, Parque Nacional Natural Gorgona (Zúñiga et al., 2014: 235).

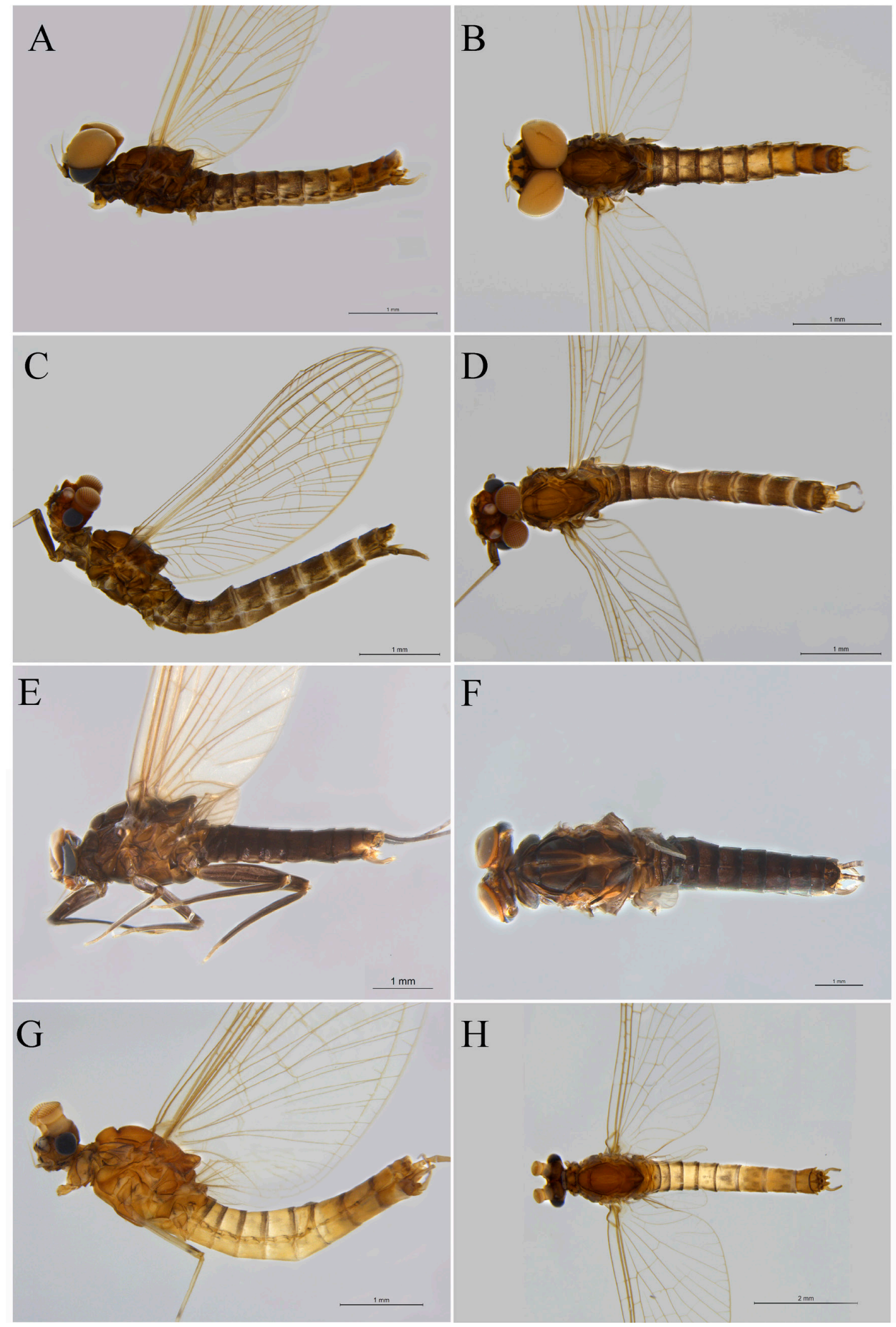

Figure 4. Habits of male imagos of Leptophlebiidae species: A) lateral view of Farrodes xingu; B) dorsal view of Farrodes xingu; C) lateral view of Hagenulopsis minuta; D) dorsal view of Hagenulopsis minuta; E) lateral view of Hydrosmilodon primanus; F) dorsal view of Hydrosmilodon primanus; G) lateral view of Miroculis (Miroculis) chiribiquete; H) dorsal view of Miroculis (Miroculis) chiribiquete. 
Additional records from Colombia: none.

\section{Hydrosmilodon primanus (Eaton, 1892) (Figs. 2D, 3E, and 4E-F)}

Previous distribution: COLOMBIA: Tolima department, Mariquita (Salinas-Jiménez et al., 2013: 364), Meta department, Acacías (Salinas-Jiménez et al., 2017: 273); COSTA RICA: Guanacaste Province (Flowers and Domínguez, 1992: 660); MEXICO: Veracruz city and Tabasco state (McCafferty, 2011: 325); PANAMA: Bocas del Toro Province (Flowers and Domínguez, 1992: 660); HONDURAS: Comayagua, El Paraiso, Intibuca and Atlantida states (Flowers and Domínguez, 1992: 660).
Additional records from Colombia: 10 male and 5 female imagos, Tolima department, San Sebastián de Mariquita, Cataratas de Medina (514'41.09”N 7453'06.97”W), 19/i/2016, light trap, deposited at CEBUC; 1 male imago and 10 nymphs, Caldas, Norcasia, Rio Manso, 15/ii/2020, light trap, male imago and 5 nymphs deposited at CEBUC, 5 nymphs at UFVB.

Miroculis (Atroari) colombiensis Savage \& Peters, 1983 (Fig. 5A)

Previous distribution: COLOMBIA: Meta department, Puerto Lopez (Savage \& Peters, 1983: 558).

Additional records from Colombia: none.

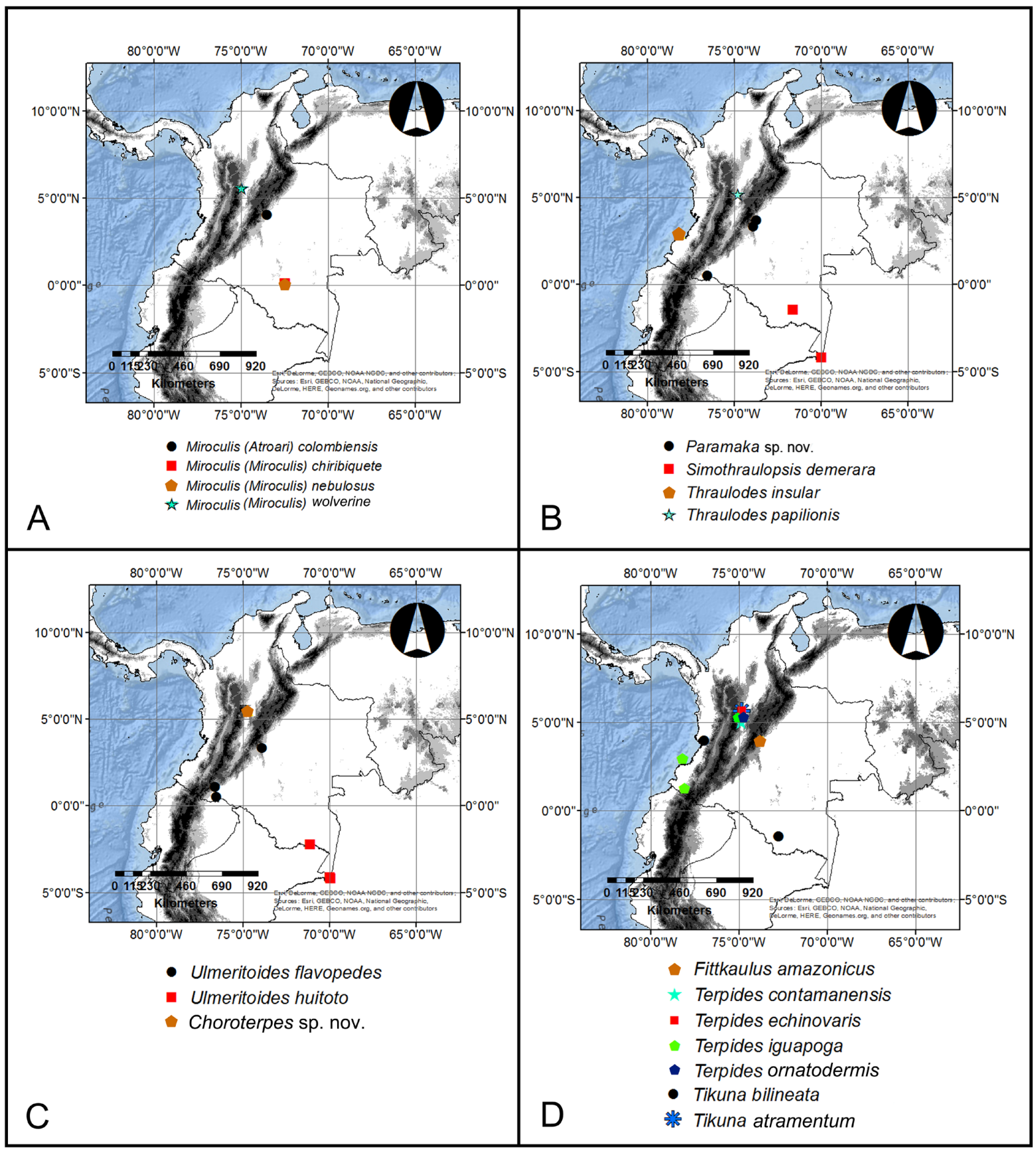

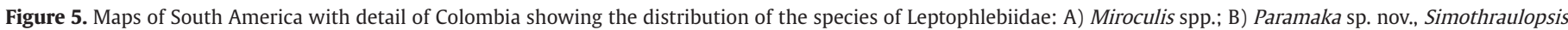
demerara and Thraulodes spp.; C) Ulmeritoides spp. and Choroterpes sp. nov.; D) Terpidinae. 
Miroculis (Miroculis) chiribiquete Peters, Domínguez \& Dereser, 2008 (Figs. 4G-H and 5A)

Previous distribution: COLOMBIA: Caquetá department, Puerto Abeja (Peters et al., 2008: 296).

Additional records from Colombia: none.

Miroculis (Miroculis) nebulosus Savage, 1987 (Fig. 5A)

Previous distribution: COLOMBIA: Caquetá department, Puerto Abeja (Peters et al., 2008: 301); VENEZUELA: Amazonas state (Savage, 1987a: 104; Chacón et al., 2009: 727).

Additional records from Colombia: none.
Miroculis (Miroculis) wolverine Costa, Almeida \& Salles, 2019 (Fig. 5A)

Previous distribution: COLOMBIA: Caldas department, Norcasia (Costa et al., 2019: 288).

Additional records from Colombia: none.

Paramaka sp. nov.* (Figs. 5B and 6A)

\section{Previous distribution: none.}

New records from Colombia: 1 male and 2 female imagos, Putumayo department, Puerto Asís, Quebrada Agua Negra (0³1'36.3”N 76³1'38.3”W), 17 and 20/xii/2015, light trap day, deposited at CEBUC; 1 male imago,

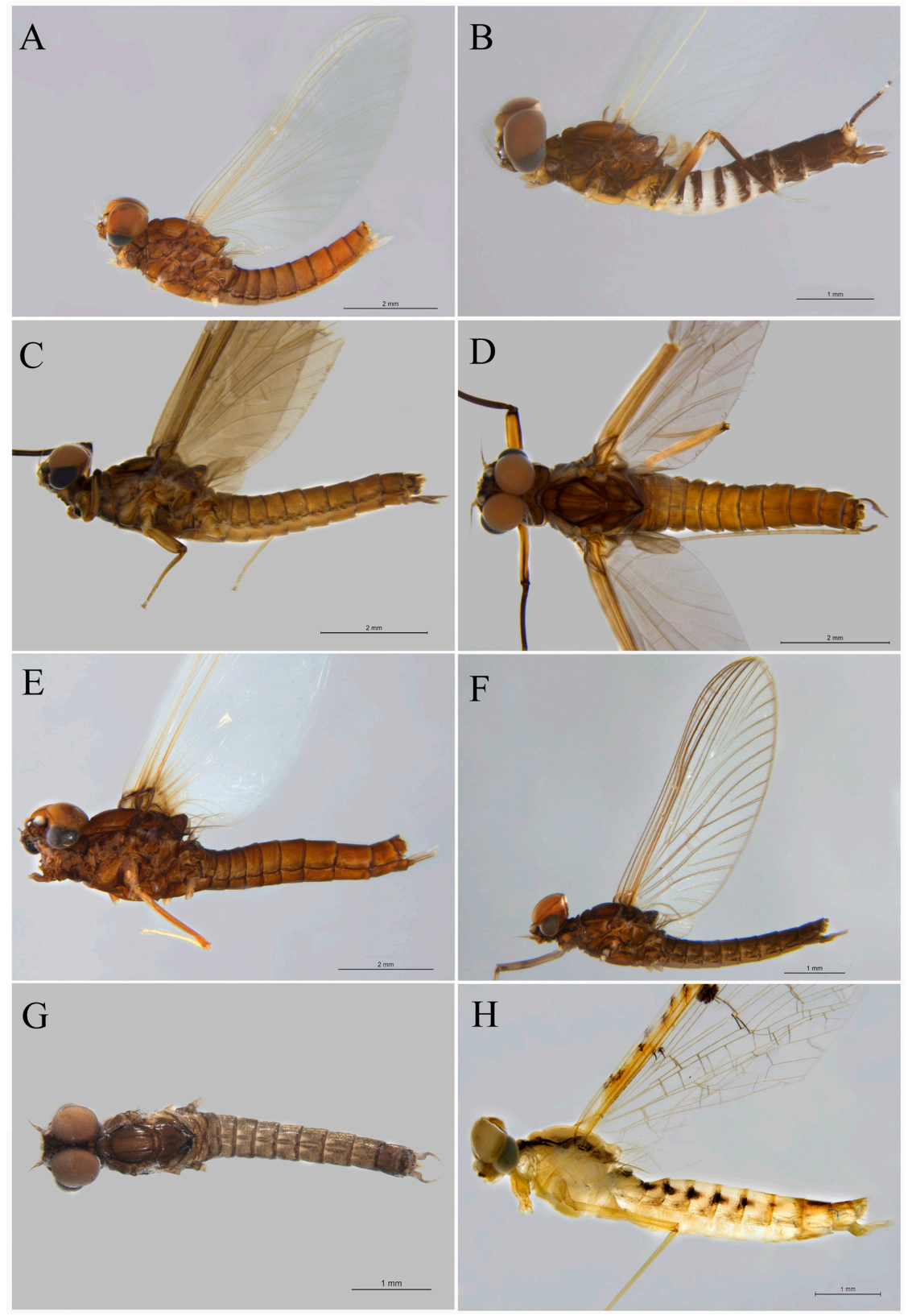

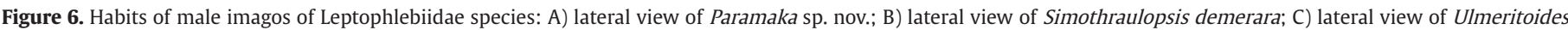

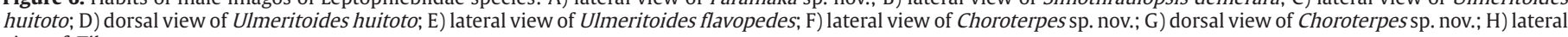
view of Tikuna atramentum. 
Meta department, San Juan de Arama, Finca la Esmeralda $\left(3^{\circ} 20^{\prime} 47.21\right.$ ”N 7353'21.87"W), 16-17/v/2015, light trap, deposited at CEBUC; 15 male and 10 female imagos, Meta department, San Martín, Caño Camoa ( $3^{\circ} 41^{\prime} 24.72$ "N $\left.73^{\circ} 41^{\prime} 59.41^{\prime \prime} \mathrm{W}\right), 04 / \mathrm{i} / 2015$, light trap, deposited at CEBUC.

Simothraulopsis demerara (Traver 1947) (Figs. 5B and 6B)

Previous distribution: COLOMBIA: Amazonas department (Zúñiga et al., 2004: 36); BRITISH GUIANA: Demerara River; SURINAME: Brokopondo District; VENEZUELA: Bolivar state (Domínguez et al., 2014: 313), Morichal District (Chacón et al., 2009: 728); FRENCH GUIANA: Sinnamary River; BRAZIL: Amazonas and Pará states (Domínguez et al., 1997: 146), Tocantins state (Boldrini and Krolow, 2017: 3), Roraima state (Gama Neto and Hamada, 2014: 285; Raimundi et al., 2017: 581), Pernambuco state (Lima et al., 2015: 5), Bahia state (Campos et al., 2016: 310; Lima et al., 2016: 217; Costa et al., 2018: 1), Maranhão state (Nascimento et al., 2020: 584), São Paulo state (Mariano and Polegatto, 2011: 594), Espírito Santo state (Salles et al., 2010: 306), and Paraná state (Faria and Salles, 2019: 376).

Additional records from Colombia: 13 male and 4 female imagos, Amazonas department, Leticia, Reserva Natural Ágape, Quebrada La Arenosa (4¹1'26.81"S 6956'11.94"W), 28/ix/2014, light trap, deposited at CEBUC.

Thraulodes colombiae (Walker, 1853)

Previous distribution: COLOMBIA (Walker, 1853: 537).

Additional records from Colombia: none.

Thraulodes insular Domínguez, Molineri \& Zúñiga, 2015 (Fig. 5B)

Previous distribution: COLOMBIA: Cauca department, Parque Nacional Natural Gorgona (Zúñiga et al., 2015: 288).

Additional records from Colombia: none.

Thraulodes laetus (Eaton, 1883)

Previous distribution: COLOMBIA (Eaton, 1883: 110).

Additional records from Colombia: none.

Thraulodes papilionis Traver \& Edmunds, 1967 (Fig. 5B)

Previous distribution: COLOMBIA: Tolima department, Honda (Traver and Edmunds, 1967: 374).

Additional records from Colombia: none.

Ulmeritoides huitoto Domínguez \& Zúñiga, 2003 (Figs. 5C and 6C-D)

Previous distribution: COLOMBIA: Amazonas department, Leticia (Domínguez and Zúñiga, 2003: 123).

Additional records from Colombia: 1 male and 1 female imagos, Amazonas department, Leticia, ( $2^{\circ} 14^{\prime} 43.03^{\prime \prime S} 71^{\circ} 05^{\prime} 49.27$ 'W), 2017, light trap, deposited at CEBUC; 1 female imago and 2 female subimagos,
Amazonas department, Leticia (4²12'21.75”S 6955’03.31”W), 28/ix/2014, light trap, deposited at UFVB.

Ulmeritoides flavopedes* (Spieth, 1943) (Figs. 5C and 6E)

Previous distribution: SURINAME: Marowijne District (Domínguez, 1995: 19); BRAZIL: Mato Grosso state (Shimano et al., 2010: 304), Pernambuco state (Lima et al., 2015: 5), Tocantins state (Boldrini and Krolow, 2017: 3), Pará state (Shimano et al., 2018: 141), Maranhão state (Nascimento et al., 2020: 588).

New records from Colombia: 1 male imago, Meta department, San Juan de Arama, Finca la Esmeralda ( $\left.3^{\circ} 20^{\prime} 47.21^{\prime \prime} \mathrm{N} 73^{\circ} 53^{\prime} 21.87^{\prime \prime} \mathrm{W}\right)$, 16-17/v/2015, light trap, deposited at CEBUC; 44 male and 4 female imagos, Putumayo department, Mocoa, Fin del Mundo ( $1^{\circ} 05^{\prime} 48.70$ ”N 76 36'12.13”W), vii/2018, light trap, deposited at CEBUC; 1 male imago, Putumayo department, Puerto Asís, Quebrada Agua Negra (0³1'36.3”N 76³1’38.3”W), 20/xii/2015, light trap day, deposited at CEBUC.

\section{Choroterpinae}

Choroterpes sp. nov.* (Figs. 5C and 6F-G)

Previous distribution: none.

New record from Colombia: 4 male imagos, Caldas department, Norcasia, Reserva Natural Río Manso, Afluente Río Manso, (5³9'25.80”N 7451’44.66”W), 04-05/iv/2017, light trap, deposited at CEBUC.

\section{Terpidinae}

Fittkaulus amazonicus Kluge, 2009 (Fig. 5D)

Previous distribution: COLOMBIA: Meta department, Acácias, Vereda La Esmeralda, Caño Seco stream (Salinas-Jiménez et al., 2018: 98); PERU: Loreto Region (Kluge, 2009: 248), Maynas Province (Kluge, 2015: 181).

Additional records from Colombia: none.

Terpides contamanensis * Kluge, 2015 (Figs. 3C and 5D)

Previous distribution: PERU: Loreto Region (Kluge, 2015; 175).

New records from Colombia: 2 female imagos, Caldas department, Norcasia, Reserva Natural Río Manso, Afluente Río Manso, (5³9'25.80”N $\left.74^{\circ} 51^{\prime} 44.66^{\prime \prime} \mathrm{W}\right), 05 / \mathrm{iv} / 2017$, light trap, deposited at UFVB; 1 male and 1 female imagos, Tolima department, Mariquita, Quebrada Granja Universidad del Tolima (500’06.2”N 7454'07.4”W), 04/xi//2017, light trap, deposited at UFVB.

Terpides echinovaris* Kluge, 2015 (Figs. 3F and 5D)

Previous distribution: PERU: Satipo Province (Kluge, 2015: 167).

New record from Colombia: 3 male imagos, Caldas department, Norcasia, Reserva Natural Río Manso, Afluente Río Manso, (5³9'25.80”N 7451’44.66”W), 05/iv/2017, light trap, deposited at UFVB. 
Terpides iguapoga Molineri, Domínguez \& Zúñiga, 2015 (Fig. 5D)

Previous distribution: COLOMBIA: Cauca department, Parque Nacional Natural Gorgona (Zúñiga et al., 2015: 283).

Additional records from Colombia: 1 male and 1 female imagos, Nariño department (Reserva Natural Ñambi) ( $1^{\circ} 18^{\prime} 00^{\prime \prime} \mathrm{N} 74^{\circ} 04^{\prime} 58.79^{\prime \prime W}$ ), iii/2013, light trap, deposited at UFVB; 1 male and 1 female imagos, Caldas department, Samaná (Parque Nacional Natural Selva de Florencia), Río San Antonio (5³0'31.7”N 7502’24.3”W), 20/x/2017, light trap, deposited at UFVB.

Terpides ornatodermis * Kluge, 2015 (Fig. 5D)

Previous distribution: PERU: Satipo Province (Kluge, 2015; 157).

New record from Colombia: 1 male subimago, Tolima department, Mariquita, Villa de los Caballeros (509'21.42"N 7453'58.32”W), 21/v/2017, reared, deposited at UFVB.

Tikuna atramentum* (Traver, 1947) (Figs. 5D and 6H)

Previous distribution: COSTA RICA: San Jose Province (Traver, 1947: 156), Guanacaste Province (Savage, et al., 2005: 4; Flowers and Ávila, 2006: 133).

New record from Colombia: 5 male and 1 female imagos, Caldas department, Norcasia, Reserva Natural Río Manso, Afluente Río Manso, ( $5^{\circ} 39^{\prime} 25.80^{\prime \prime} \mathrm{N} 74^{\circ} 51^{\prime} 44.66$ ”W), 05/iv/2017, light trap, deposited at UFVB.

Tikuna bilineata (Needham \& Murphy, 1924) (Fig. 5D)

Previous distribution: COLOMBIA: Amazonas department, La Chorrera (Needham and Murphy, 1924: 48); SURINAME: Surinam River (Traver, 1947: 156); PERU and SURINAME (Hubbard, 1982: 264); BRAZIL: Pará state; ECUADOR: Pastaza Province; SURINAME: Wijne District and VENEZUELA: Zulia state (Peters et al., 2005: 52; Chacón et al., 2009: 728); PERU: Madre de Dios department, Ucayali Province, and Maynas Province (Sweeney et al., 2009: 315; Kluge, 2015: 182); BRAZIL: Mato Grosso and Pará states (Boldrini et al., 2009: 225; Shimano et al., 2011: 250; Brasil et al., 2013: 262; Shimano et al., 2013: 36), Espírito Santo state (Angeli et al., 2015: 202), Tocantins state (Boldrini and Krolow, 2017: 3), Goiás state (Raimundi, 2019: 40), and Maranhão state (Nascimento et al., 2020: 587).

Additional records from Colombia: 1 male imago, Caldas department, Norcasia, Reserva Natural Río Manso, Afluente Río Manso, (5³9’25.80”N 7451'44.66"W), 05/iv/2017, light trap, deposited at UFVB; 1 female imago, Valle del Cauca department, Bajo Calima, Buenaventura, Quebrada La Larga (359'47"N 7658'28”W), 12/xii/2017, light trap, deposited at UFVB.

\section{Discussion}

As expected, Hagenulinae is the most species-rich subfamily in Colombia, currently represented by 10 genera and 25 species. Among them, Farrodes (five species), Miroculis (four) and Thraulodes (four) stand out as the most diverse, closely followed by Atopophlebia and Hagenulopsis (three species each). In the case of Thraulodes, however, it should be noted, as previously stated, that additional species will be treated elsewhere. Terpidinae is represented by its three genera and seven species, while Choroterpinae is represented by a single new species of Choroterpes. Unidentified species of this genus have been previously reported from Colombia based on nymphs (Peters et al., 2005; Gutiérrez and Reinoso-Flórez, 2010; García et al., 2013), and for the first time adults were found. These are the only records of the world-widely distributed Choroterpinae in South America. The absence of Atalophlebiinae in Colombia, at least among the previous and new records, was somewhat expected. Members of this subfamily include cold-adapted mayflies (Santos et al., 2018; Monjardim et al., 2020) that, in South America, are mostly restricted to Patagonia and some marginal areas along the southern portion of South American Transition Zone (Molineri et al., 2020) (the only exception is the genus Massartella Lestage, found in Brazil and Venezuela). It is very unlikely, therefore, that even additional collections in the Paramo, an area poorly represented at the CEBUC, would lead to the discovery of some Atalophlebiinae in the country.

Of the 33 species of Leptophlebiidae treated in this work, 14 are registered only to Colombia while 19 are present in other countries, such as Brazil (eight), Peru (five), Costa Rica (five), and Panama (four). Given the current distribution of these species, the fauna of Leptophlebiidae in Colombia seems to be a mosaic of elements from distinct biogeographic dominions (see Morrone, 2014). Some endemic, such as Atopophlebia fortunensis, Farrodes caribbianus, and Hydrosmilodon primanus(from the Pacific Dominion) or Askola emmerichi, Ulmeritoides flavopedes, and Hagenulopsis minuta (from the Boreal Brazilian Dominion). While others are present in more than one biogeographic dominion. For example, Fittkaulus amazonicus (northwestern portion of the South Brazilian dominion and Boreal Brazilian), and Terpides contamanensis and Terpides echinovaris (northwestern portion of the South Brazilian Dominion and Pacific).

The new and additional records presented in this work contribute significantly to our understanding of the knowledge of the order Ephemeroptera from Colombia. Furthermore, this work highlights the richness of the different biogeographical regions of Colombia and confirms that diversity in this country is underestimated. Our results also demonstrate the importance of biological collections as a depository of biodiversity and suggest that the knowledge of Ephemeroptera in Colombia could expand with the increase in the sampling effort, since many regions of the country have not been studied.

\section{Acknowledgments}

We thank the Universidad de Caldas for providing funds to LGD to conduct the sampling of Ephemeroptera in several projects. We also thank Dr. Tito Bacca (Universidad del Tolima), Milton Montaño, MSc Camilo Llano, MSc Ana Meza and students of the Laboratorio de Colecciones Biológicas of Universidad de Caldas for assistance with sampling specimens deposited in CEBUC collection. We thank ISAGEN for facilitating the sampling of macroinvertebrates in the east of the department of Caldas. We also thank Dr. Og DeSouza (Universidade Federal de Viçosa) for facilitating the use of optic equipment. This study was financed in part by the Conselho Nacional de Desenvolvimento Científico e Tecnológico (CNPq) to JFM (process \# 162813/2018-0) and to FFS (processes \# 305847/2015-5 and 309666/2019-8).

\section{Conflicts of interest}

The authors declare no conflict of interest. 


\section{Author contribution statement}

LGD conceived the research, conducted the field work and take some imagens. FFS identified the species and elaborated the discussion. ICH obtained some imagens and produced the final plates, and included the world distribution of the lineages. JFM wrote the document and elaborated the maps. All authors critically reviewed the manuscript and approved the final version of this paper.

\section{References}

Andrade, M. G., 2011. Estado del conocimiento de la biodiversidad en Colombia y sus amenazas. Consideraciones para fortalecer la interacción ambiente-política. Rev. Acad. Colomb. Cienc. Exactas Fis. Nat. 35 (137), 491-507.

Angeli, K. B., do Rozário, E. M. M., Salles, F. F., 2015. Checklist of Ephemeroptera (Insecta) from São Mateus River Basin, Espírito Santo, Brazil. Rev. Bras. Entomol. 59 (3), 197-204. http://dx.doi. org/10.1016/j.rbe.2015.06.004.

Boldrini, R., Krolow, T. K., 2017. New records of Ephemeroptera (Insecta) from Tocantins state, northern Brazil. Check List 13 (2), 1-5. http:// dx.doi.org/10.15560/13.2.2067.

Boldrini, R., Salles, F. F., Cabette, H. R., 2009. Contribution to the taxonomy of the Terpides lineage (Ephemeroptera: Leptophlebiidae). J. Ann. Limnol. Int. J. Lim. 45 (4), 219-229. http://dx.doi.org/10.1051/ $\operatorname{limn} / 2009029$.

Brasil, L. S., Shimano, Y., Batista, J. D., Cabette, H. S., 2013. Effects of environmental factors on community structure of Leptophlebiidae (Insecta, Ephemeroptera) in Cerrado streams, Brazil. Iheringia Ser. Zool. 103 (3), 260-265. http://dx.doi.org/10.1590/S007347212013000300008.

Campos, R., Mariano, R., Calor, A. R., 2016. Mayflies (Ephemeroptera) from Reserva Ecológica Michelin, Bahia, Brazil. Aquat. Insects 37 (4), 303-315. http://dx.doi.org/10.1080/01650424.2016.1267769.

Campos, R., Mariano, R., Calor, A. R., 2019. Askola Peters 1969 (Ephemeroptera: Leptophlebiidae: Atalophlebiinae): an updated review under cladistics approach. Zool. Anz. 283, 69-92. http:// dx.doi.org/10.1016/j.jcz.2019.08.006.

Chacón, M. M., Pescador, M. L., Hubbard, M. D., Segnini, S., 2009. Mayflies (Insecta: Ephemeroptera) from Venezuela. Check List 5 (3), 723-731. http://dx.doi.org/10.15560/5.3.723.

Costa, S. S., Souza, F. N., Nogueira, M. A. M., Santos, E. P. D., Sousa, M. M. L. D., Silva, V. D. A., Almeida, E., Mariano, R., 2018. Leptophlebiidae (Insecta: Ephemeroptera) from state of Bahia, Brazil. Biota Neotrop. 18 (1), 1-6. http://dx.doi.org/10.1590/1676-0611-bn-2017-0386.

Costa, V., Almeida, T. B., Salles, F. F., 2019. Description of two related new species of Miroculis Edmunds, 1963 (Ephemeroptera: Leptophlebiidae) from Brazil and Colombia. Zootaxa 4695 (3), 283-294. http://dx.doi. org/10.11646/zootaxa.4695.3.3.

Dias, L. G., Marulanda, J. F., 2019. First records of the genera Macunahyphes and Microphlebia (Insecta: Ephemeroptera) from Colombia. Bol. Cient. Cent. Museos Mus. Hist. Nat. 23 (2), 309-315. https://doi. org/10.17151/bccm.2019.23.2.18.

Domínguez, E., 1995. Cladistic analysis of the Ulmeritus-Ulmeritoides group (Ephemeroptera, Leptophlebiidae), with descriptions of five new species of Ulmeritoides. J. N.Y. Entomol. Soc. 103 (1), 15-38.

Domínguez, E., 1999. Systematics, cladistics and biogeography of the American genus Farrodes (Ephemeroptera: Leptophlebiidae: Atalophlebiinae). Zool. J. Linn. Soc. 126 (2), 155-189. http://dx.doi. org/10.1111/j.1096-3642.1999.tb00152.x.

Domínguez, E., Grillet, M. E., Nieto, C., Molineri, C., Guerrero, E., 2014. Ephemeroptera from the Venezuelan Guayanass Uplands: Families
Leptophlebiidae, Euthyplociidae and Oligoneuriidae. Zootaxa 3827 (3), 301-317. http://dx.doi.org/10.11646/zootaxa.3827.3.1.

Domínguez, E., Molineri, C., Mariano, R., 2009. Revision of the South American species of Hagenulopsis Ulmer and Askola Peters (Ephemeroptera: Leptophlebiidae) with description of six new species. Zootaxa 2142 (1), 29-44. http://dx.doi.org/10.11646/ zootaxa.2142.1.3.

Domínguez, E., Molineri, C., Nieto, C., Zúñiga, M. D. C., 2019. Lista de Especies de Ephemeroptera Sudamericanos. Available in: http:// ibn-conicet.gob.ar/ephemeroptera-sudamericanos/ (accessed 18 March 2020).

Domínguez, E., Molineri, C., Pescador, M. L., Hubbard, M. D., Nieto, C., 2006. Ephemeroptera of South America Aquatic Biodiversity of Latin America. Vol. 1. Pensoft, Sofia-Moscow.

Domínguez, E., Molineri, C., Peters, W. L., 1996. Ephemeroptera from Central and South America: new species of the Farrodes bimaculatus group with a key for the males. Stud. Neotrop. Fauna Environ. 31 (2), 87-101. http://dx.doi.org/10.1076/snfe.31.2.87.13325.

Domínguez, E., Peters, W. L., Peters, J. G., Savage, H. M., 1997. The imago of Simothraulopsis Demoulin with a redescription of the nymph (Ephemeroptera: Leptophlebiidae: Atalophlebiinae). Aquat. Insects 19 (3), 141-150. http://dx.doi.org/10.1080/01650429709361648.

Domínguez, E., Zúñiga, M. D. C., 2003. First generic record and description of a new species of Ulmeritoides(Ephemeroptera: Leptophlebiidae) from Colombia. In: Gaino, E. (Ed.), Research Update on Ephemeroptera \& Plecoptera. Università di Perugia, Bari, pp. 123-125.

Domínguez, E., Zúñiga, M. D. C., 2009. First description of the larva of Farrodes roundsi (Traver) (Ephemeroptera: Leptophlebiidae: Atalophlebiinae) with comments on its phylogenetic relationships. Aquat. Insects 31 (1), 73-81. http://dx.doi.org/10.1080/01650420802544297.

Eaton, A. E., 1881. An announcement of new genera of the Ephemeridae. Entomol. Mon. Mag. 17, 191-197.

Eaton, A. E., 1883. A revisional monograph of recent Ephemeridae or mayflies. In: Linnean Society of London (Ed.), Transactions of the Linnean Society of London. London, 352 pp. (Second Series. Zoology, 2). https://doi.org/10.1111/j.1096-3642.1883.tb01550a.x.

Eaton, A. E., 1892. Fam. Ephemeridae. Biol. Centrali-Americana 38, 1-16.

Faria, L. R. R., Salles, F. F., 2019. An unexpected record of Simothraulopsis Demoulin, 1966 (Ephemeroptera, Leptophlebiidae) in the Paraná Basin, Brazil. Check List 15 (3), 375-378. http://dx.doi.org/10.15560/15.3.375.

Flowers, R. W., 1980. Atopophlebia fortunensis, a new genus and species from Panama (Leptophlebiidae: ephemeroptera). Fla. Entomol. 63 (1), 162-165. http://dx.doi.org/10.2307/3494670.

Flowers, R. W., 1987. New species and life stages of Atopophlebia (Ephemeroptera: Leptophlebiidae: Atalophlebiinae). Aquat. Insects 9 (4), 203-209. http://dx.doi.org/10.1080/01650428709361297.

Flowers, R. W., Ávila, S., 2006. Biogeographical and ecological notes on the genus Tikuna Savage, Flowers, and Porras (Ephemeroptera: Leptophlebiidae) from Central and South America. Entomol. News 117 (2), 133-138. http://dx.doi.org/10.3157/0013-872X(2006)117[ 133:BAENOT]2.0.CO;2.

Flowers, R. W., Domínguez, E., 1992. New genus of Leptophlebiidae (Ephemeroptera) from Central and South America. Ann. Entomol. Soc. Am. 85 (6), 655-661. http://dx.doi.org/10.1093/aesa/85.6.655.

Gama Neto, J. D. L., Hamada, N., 2014. Leptophlebiidae (Ephemeroptera) of the Serra do Tepequém, Roraima State, Brazil: new records and description of two new species. Zootaxa 3900 (2), 279-286. http:// dx.doi.org/10.11646/zootaxa.3900.2.8.

García, L. F., Hoyos, D. C., Dias, L. G., 2013. Primer reporte de Choroterpes (Ephemeroptera: Leptophlebiidae) para Caldas, Colombia. Rev. Colomb. Entomol. 39 (1), 164-165. 
Godunko, R. J., Sroka, P., Soldán, T., Bojková, J., 2015. The higher phylogeny of Leptophlebiidae (Insecta: Ephemeroptera), with description of a new species of Calliarcys Eaton, 1881. Arthropod Syst. Phylogeny 73 (2), 259-279.

Gutiérrez, C., Reinoso-Flórez, G., 2010. Géneros de ninfas del orden Ephemeroptera (Insecta) del departamento del Tolima, Colombia: listado preliminar. Biota Colomb. 11 (1-2), 23-32.

Hubbard, M. D., 1982. Catálogo abreviado de Ephemeroptera da América do Sul. Pap. Avulsos Zool. 34 (24), 257-282.

Kluge, N. J., 2009. Higher system of Atalophlebiinae (Leptophlebiidae) with description of three new species of Terpides s.l. from Peruvian Amazonia. Russ. Entomol. J. 18 (4), 243-256.

Kluge, N. J., 2015. Contribution to the knowledge of Terpidinae Kluge 2009 (Ephemeroptera: leptophlebiidae). Zootaxa 3999 (2), 151-189. http://dx.doi.org/10.11646/zootaxa.3999.2.1.

Lima, L. R. C., Knapp, W., Docio, L., 2016. New records of mayflies (Insecta: Ephemeroptera) from Bahia state, northeastern Brazil. Entomotrópica 31 (25), 212-220.

Lima, L. R., Salles, F. F., Pinheiro, U., 2012. Ephemeroptera (Insecta) from Pernambuco State, northeastern Brazil. Rev. Bras. Entomol. 56 (3), 304-314. http://dx.doi.org/10.1590/S0085-56262012005000043.

Lima, L. R., Salles, F. F., Pinheiro, U., 2015. New records of mayflies (Ephemeroptera: Insecta) from Pernambuco state, northeastern Brazil. Check List 11 (3), 1-7. http://dx.doi.org/10.15560/11.3.1652.

Mariano, R., Polegatto, C., 2011. Checklist de Ephemeroptera do Estado de São Paulo, Brasil. Biota Neotrop. 11 (1a, Suppl.1), 593-599. http:// dx.doi.org/10.1590/S1676-06032011000500025.

McCafferty, W. P., 2011. New Mexican and Central American Ephemeroptera records, with first species checklists for Mexican states. Trans. Am. Entomol. Soc. 137 (3-4), 317-327. https://doi.org/10.3157/061.137.0310.

Meyer, M. D., Baumgardner, D. E., McCafferty, W. P., 2008. The Ephemeroptera of Central America. Part 2: nicaragua. Trans. Am. Entomol. Soc. 134 (1), 133-146. http://dx.doi.org/10.3157/00028320(2008)134[133:TEOCAP]2.0.CO;2.

Molineri, C., Dias, L. G., Gonzalez, I., Nunez-Avellaneda, A., 2019. Nymphal description of Tricorythodes zagaia n. Comb. and Tricorythodes pemonensis n. Comb (Ephemeroptera: Leptohyphidae) and first records from Colombia. Zootaxa 4585 (2), 395-400. http://dx.doi. org/10.11646/zootaxa.4585.2.13.

Molineri, C., Nieto, C., Santos, D. A., Emmerich, D., Zúñiga, M. C., Fierro, P., Pessacq, P., Gomez, D., Márquez, J. A., Príncipe, R. E., Valdovinos Zarges, C., Domínguez, E., 2020. Do mayflies (Ephemeroptera) support a biogeographic transition zone in South America? J. Biogeogr. 1-14. http://dx.doi.org/10.1111/jbi.13868.

Monjardim, M., Paresque, R., Salles, F. F., 2020. Phylogeny and classification of Leptophlebiidae (Ephemeroptera) with and emphasis on Neotropical fauna. Syst. Entomol. 45 (2), 415-429. http://dx.doi. $\operatorname{org} / 10.1111 /$ syen.12402.

Morrone, J. J., 2014. Biogeographical regionalisation of the Neotropical region. Zootaxa 3782 (1), 1-110. http://dx.doi.org/10.11646/ zootaxa.3782.1.1.

Mosquera, S., Zúñiga, M. D. C., Alba-Tercedor, J., 2001. Atopophlebia fortunensis Flowers (Ephemeroptera: Leptophlebiidae) and Caenis chamie, Alba-Tercedor and Mosquera (Ephemeroptera: Caenidae). Notes on Their Biology and Ecology. In: Domínguez, E. (Ed.), Trends in Research in Ephemeroptera and Plecoptera, Springer, Boston, MA, pp. 157-160. https://doi.org/10.1007/978-1-4615-1257-8_19.

Myers, N., Mittermeier, R. A., Mittermeier, C. G., Da Fonseca, G. A., Kent, J., 2000. Biodiversity hotspots for conservation priorities. Nature 403 (6772), 853-858. http://dx.doi.org/10.1038/35002501.

Nascimento, J. M. C. D., Barcelos-Silva, P., Salles, F. F., 2011. Two-winged Leptophlebiidae (Ephemeroptera) from Brazil: new species, records and stage description. Aquat. Insects 33 (3), 191-201. http://dx.doi. org/10.1080/01650424.2011.597408.

Nascimento, S. R., Lima, L. R. C., Azevêdo, C. A. S., 2020. Leptophlebiidae Banks, 1900 (Insecta, Ephemeroptera) from Maranhão state, Brazil. Check List 16 (3), 579-591. http://dx.doi.org/10.15560/16.3.579.

Needham, J. G., Murphy, H. E., 1924. Neotropical mayflies. Bulletin of the Lloyd Library Number 24. Entomol. Ser. 4, 1-79.

O'Donnell, B. C., Jockusch, E. L., 2008. Phylogenetic relationships of leptophlebiid mayflies as inferred by histone $\mathrm{H} 3$ and $28 \mathrm{~S}$ ribosomal DNA. Syst. Entomol. 33 (4), 651-667. http://dx.doi.org/10.1111/j.13653113.2008.00434.x.

Peters, J. G., Domínguez, E., Dereser, A. C., 2008. Species of Miroculis from the Serranía de Chiribiquete in Colombia (Ephemeroptera: Leptophlebiidae: Atalophlebiinae). In: Hauer, F.R., Stanford, J., Newell, R. (Eds.), International Advances in the Ecology, Zoogeography, and Systematics of Mayflies and Stoneflies. University of California Press, Berkeley, pp. 295-305.

Peters, J. G., Flowers, R. W., Hubbard, M. D., Domínguez, E., Savage, H. M., 2005. New records and combinations for Neotropical Leptophlebiidae (Ephemeroptera). Zootaxa 1054 (1), 51-60. http:// dx.doi.org/10.11646/zootaxa.1054.1.6.

Peters, W., 1980. Phylogeny of the Leptophlebiidae (Ephemeroptera): an introduction. In: Williams, D. D. (Ed.), Advances in Ephemeroptera Biology. New York, Plenum Press, pp. 33-43. http://dx.doi. org/10.1007/978-1-4613-3066-0_3.

Peters, W. L., Domínguez, E., 2001. The identity of Hagenulopsis minuta Spieth (Leptophlebiidae: Atalophlebiinae). In: Domínguez, E. (Ed.), Trends in Research in Ephemeroptera and Plecoptera. Springer, Boston, MA, pp. 353-358. http://dx.doi.org/10.1007/978-1-4615-1257-8_40

Poveda, G., Álvarez, D. M., Rueda, O. A., 2010. Hydro-climatic variability over the Andes of Colombia associated with ENSO: a review of climatic processes and their impact on one of the Earth's most important biodiversity hotspots. Clim. Dyn. 36 (11-12), 2233-2249. https://doi.org/10.1007/s00382-010-0931-y.

Raimundi, E. A., 2019. Contribution to the knowledge of Ephemeroptera (Insecta) from Goiás state, Brazil. J. Insect Biodivers. 12 (2), 33-47. http://dx.doi.org/10.12976/jib/2019.12.2.1.

Raimundi, E. A., Nascimento, J. M. C. D., Barroso, P. C. S., Hamada, N., Boldrini, R., 2017. Three new species of Miroculis from the Serra da Mocidade National Park, Roraima State, Brazil, with new records and checklist of the Leptophlebiidae (Ephemeroptera). Zootaxa 4317 (3), 573-583. http://dx.doi.org/10.11646/zootaxa.4317.3.8.

Rozo, M. P., Salinas-Jiménez, L. G., 2016. Inventario del orden Ephemeroptera (Insecta) en la quebrada Coquital, Serranía de Tripogadí, Departamento del Chocó, Colombia. Entomotrópica 31 (1), 1-13.

Salinas-Jiménez, L. G., Flowers, R. W., Dias, L. G., 2013. First record of Hydrosmilodon primanus(Eaton) (Ephemeroptera, Leptophlebiidae) from South America. Biota Neotrop. 13 (1), 363-365. http://dx.doi org/10.1590/S1676-06032013000100038.

Salinas-Jiménez, L. G., Rojas-Peña, J. I., Osorio-Ramírez, D. P., Caro-Caro, C. I., 2017. New records of Ephemeroptera from the Colombian Orinoco river basin of the Meta department. Rev. Colomb. Entomol. 44 (1), 147. http://dx.doi.org/10.25100/socolen.v44i1.6758.

Salinas-Jiménez, L. G., Suárez-Mantilla, E. Y., Orejarena-Cuartas, J. A., Torres-Mora, M., 2018. Primer registro de la ninfa de Fittkaulus amazonicus Kluge (Ephemeroptera, Leptophlebiidae) para Colombia y ampliación de la distribución a la cuenca del Río Orinoco. Bol. Cient. Cent. Museos Mus. Hist. Nat. 22 (1), 97-101. https://doi. org/10.17151/bccm.2018.22.1.8.

Salles, F. F., Boldrini, R., 2019. A new genus of the subtribe Hermanellina (Ephemeroptera: Leptophlebiidae: Atalophlebiinae) from Northern 
Brazil with accounts on the systematics of the group. Insect Syst. Evol. 1, 1-17. https://doi.org/10.1163/1876312X-00002300.

Salles, F. F., Marulanda, J. F., Dias, L. G., 2018. Two new species of Atopophlebia Flowers, 1980 (Ephemeroptera, Leptophlebiidae) from Colombia. Zootaxa 4446 (1), 138-150. http://dx.doi.org/10.11646/ zootaxa.4446.1.10.

Salles, F. F., Nascimento, J. M. C., Massariol, F. C., Angeli, K. B., Silva, P. B., Rúdio, J. A., Boldrini, R., 2010. Primeiro levantamento da fauna de Ephemeroptera (Insecta) do Espírito Santo, sudeste do Brasil. Biota Neotrop. 10 (1), 293-307. http://dx.doi.org/10.1590/S167606032010000100025.

Salles, F. F., Nascimento, J. M. C., Monjardim, M., Paresque, R., Hamada, N., Dominguez, E., 2020a. Diamantina: An endemic new genus of Neotropical Atalophlebiinae (Ephemeroptera: Leptophlebiidae) evidenced by morphological and molecular data. Zool. Anz. 284, 30-42. http://dx.doi.org/10.1016/j.jcz.2019.10.005.

Salles, F. F., Molineri, C., Nieto, C., Lima, L. R. C., Dias, L. G., Boldrini, R., Mariano, R., Domínguez, E., 2020b. Ephemeroptera da América do Sul. Available in: http://ephemeroptera.com.br/ (accessed 8 August 2020).

Santos, D. A., Molineri, C., Nieto, C., Zuñiga, M. C., Emmerich, D., Fierro, P., Pessacq, P., Rios-Touma, B., Márquez, J., Gomez, D., Salles, F. F., Encalada, A. C., Príncipe, R., Gómez, G. C., Valdovinos Zarges, C., Domínguez, E., 2018. Cold/Warm stenothermic freshwater macroinvertebrates along altitudinal and latitudinal gradients in Western South America: A modern approach to an old hypothesis with updated data. J. Biogeogr. 45 (7), 1571-1581. http://dx.doi. org/10.1111/jbi.13234.

Santos, G. C., Boldrini, R., 2016. Askola emmerichi Domínguez, Molineri \& Mariano, 2009 (Ephemeroptera: Leptophlebiidae), novo registro para o estado de Roraima, Brasil. Bol. Mus. Integrado Roraima 10 (1), 2317-5206.

Santos, R. P., Moreto, V., Mariano, R., 2019. Intersexuality in Farrodes Peters, 1971 (Ephemeroptera: Leptophlebiidae: Atalophlebiinae) from Brazil. Rev. Bras. Entomol. 63 (3), 202-204. http://dx.doi. org/10.1016/j.rbe.2019.05.008.

Sartori, M., Brittain, J. E., 2015. Order Ephemeroptera. In: Rogers, D.C., Thorp, J.H. (Eds.), Thorp and Covich's Freshwater Invertebrates. Academic Press, Amsterdam, pp. 873-891. http://dx.doi.org/10.1016/ B978-0-12-385026-3.00034-6

Savage, H. M., 1987a. Two new species of Miroculisfrom Cerro de la Neblina, Venezuela with new distribution records for Miroculis fittkaui and Microphlebia surinamensis (Ephemeroptera: leptophlebiidae). Aquat. Insects 9 (2), 97-108. http://dx.doi.org/10.1080/01650428709361279.

Savage, H. M., 1987b. Biogeographic classification of the Neotropical Leptophlebiidae (Ephemeroptera) based upon geological centers of ancestral origin and ecology. Stud. Neotrop. Fauna Environ. 22 (4), 199-222. http://dx.doi.org/10.1080/01650528709360734.

Savage, H. M., Domínguez, E., 1992. A new genus of Atalophlebiinae (Ephemeroptera: Leptophlebiidae) from northern South America. Aquat. Insects 14 (4), 243-248. http://dx.doi.org/10.1080/01650429209361489.

Savage, H. M., Flowers, R. W., Porras, W., 2005. Rediscovery of Choroterpes atramentum in Costa Rica, type species of Tikuna new genus (Ephemeroptera: Leptophlebiidae: Atalophlebiinae), and its role in the" Great American Inter-change. Zootaxa 932 (1), 1-14. http:// dx.doi.org/10.11646/zootaxa.932.1.1.

Savage, H. M., Peters, W. L., 1983. Systematics of Miroculis and related genera from northern South America (Ephemeroptera: leptophlebiidae). Trans. Am. Entomol. Soc. 108 (4), 491-600. Available in: https:// www.jstor.org/stable/25078309 (accessed 8 August 2020).

Shimano, Y., Cabette, H. S., Salles, F. F., Juen, L., 2010. Composição e distribuição da fauna de Ephemeroptera (Insecta) em área de transição Cerrado-Amazônia, Brasil. Iheringia Ser. Zool. 100 (4), 301-308. http://dx.doi.org/10.1590/S0073-47212010000400004.

Shimano, Y., Salles, F. F., Cabette, H. S. R., 2011. Ephemeroptera (Insecta) ocorrentes no Leste do Estado do Mato Grosso, Brasil. Biota Neotrop. 11 (4), 239-253. http://dx.doi.org/10.1590/S1676-06032011000400021.

Shimano, Y., Juen, L., Salles, F. F., Nogueira, D. S., Cabette, H. S. R., 2013. Environmental and spatial processes determining Ephemeroptera (Insecta) structures in tropical streams. Ann. Limnologie-International J. Limnol. 49 (1), 31-41. http://dx.doi.org/10.1051/limn/2013036.

Shimano, Y., Cardoso, M., Juen, L., 2018. Estudos ecológicos com Ephemeroptera (Insecta): O esforço amostral pode ser reduzido sem perder informações ecológicas e taxonômicas? Acta Amazon. 48 (2), 137-145. http://dx.doi.org/10.1590/1809-4392201700583.

Spieth, H., 1943. Taxonomic studies on the Ephemeroptera. III. Some interesting Ephemerids from Surinam and other neotropical localities. Am. Mus. Novit. 1244, 1-13.

Sweeney, B. W., Flowers, R. W., Funk, D. H., Ávila, S. A., Jackson, J. K., 2009. Mayfly communities in two Neotropical lowland forests. Aquat. Insects 31 (Suppl.1), 311-318. http://dx.doi.org/10.1080/01650420902833863.

Traver, J. R., 1943. New Venezuelan mayflies. Bol. Entomol. Venez. 2, 49-57.

Traver, J. R., 1947. Notes on Neotropical Mayflies, Part II, Baetidae, Subfamily Leptophlebiinae. Rev. Etol. 18, 149-160.

Traver, J. R., Edmunds, J. G. F., 1967. A revision of the genus Thraulodes (Ephemeroptera: leptophlebiidae). Miscellaneous Publ. Entomol. Soc. Am. 5 (8), 351-402.

Walker, F., 1853. Ephemerinae. In: British Museum (Ed.), Catalogue of the Specimens of Neuropterus Insects in the Collection of the British Museum. Part III (Termitidae and Ephemeridaé). London, pp. 553-585.

Zúñiga, M. D. C., Hernández, A. M. R., Aguilera, S. M., 1997. Biological aspects of Ephemeroptera in rivers of southwestern Colombia (South America). In: Taller Internacional sobre Sistemática y Ecología de Ephemeroptera como Bioindicador de Calidad de Agua, 1997, Santiago de Cali, Colombia. Anales. Universidad Del Valle, Colombia, pp. 1-13.

Zúñiga, M. D. C., Molineri, C., Domínguez, E., 2004. El Orden Ephemeroptera (Insecta) en Colombia (No. Doc. 21585) CO-BAC, Bogotá.

Zúñiga, M. D. C., Cardona, W., Molineri, C., Mendivil, J., Cultid, C., Chará, A. M., Giraldo, A., 2014. Entomofauna acuática del Parque Nacional Natural Gorgona, Pacífico colombiano, con énfasis en Ephemeroptera y Plecoptera. Rev. Biol. Trop. 62 (2), 221-241. http:// dx.doi.org/10.15517/rbt.v62i0.16278.

Zúñiga, M. D. C., Molineri, C., Domínguez, E., Cardona, W., 2015. Leptophlebiidae (Insecta: Ephemeroptera) from Gorgona Island National Natural Park (Tropical Eastern Pacific, Colombia) with the description of two new species. Ann. Limnol. - Int. J. Lim. 51 (4), 281-296. http://dx.doi.org/10.1051/limn/2015026. 